\title{
Peran orang tua dan guru dalam memotivasi peserta didik sekolah dasar di masa pandemi
}

\author{
Yosi Fimala $^{\left.1^{*}\right)}$, Neviyarni $S^{1}$, Irda Murni ${ }^{1}$ \\ Universitas Negeri Padang
}

\section{Article Info \\ Article history: \\ Received April $19^{\text {th }}, 2021$ \\ Revised May $15^{\text {th }}, 2021$ \\ Accepted Jun 26 ${ }^{\text {th }}, 2021$}

\section{Keyword:}

Motivasi

Peserta didik

Sekolah dasar

\begin{abstract}
Pendidikan merupakan aspek yang terpenting pada kehidupan. Namun saat ini proses pendidikan mendapatkan rintangan yang berat karena dengan adanya pandemi COVID - 19 ini sistem pembelajaran awalnya tatap muka beralih menjadi tatap maya/ virtual. Dalam pembelajaran seperti saat sekarang ini motivasi dibutuhkan peserta didik dari orang tua dan guru. Orang tua dan guru berperan dalam memotivasi siswa belajar. Motivasi adalah dorongan untuk melakukan suatu kegiatan. Penelitian ini menggunakan metode study literatur research atau studi kepustakaan dengan mengkaji jurnal yang memiliki kaitan atau hubungan dengan strategi atau upaya orang tua dan guru dalam meningkatkan motivasi peserta didik di sekolah dasar. Hasil penelitian adalah peran guru dan orang tua dalam rangka memotivasi peserta didik belajar di rumah. Kesimpulannya yaitu dengan cara komunikasi persuasif, pendekatan personal, mengatur waktu belajar, cara belajar anak, mengawasi perkembangan anak, melakukan pendampingan, memfasilitasi sarana prasarana belajar, membangun kolaborasi antara orang tua dan guru, memaksimalkan peran sebagai fasilitator dan motivator, melengkapi program atau aturan terstruktur dalam belajar dirumah, menyiapkan media belajar yang inovatif dan mudah diakses serta mudah digunakan, memberikan dukungan untuk mengerjakan tugas, memberi kesempatan bagi anak untuk menemukan minat dan bakat yang ada pada dirinya, serta memfasilitasi sarana dan prasarana kelengkapan belajar anak, serta membantu anak jika mendapat kesulitan belajar.
\end{abstract}

(C) 2021 The Authors. Published by IICET

This is an open access article under the CC BY-NC-SA license (https://creativecommons.org/licenses/by-nc-sa/4.0)

\section{Corresponding Author:}

Yosi Fimala,

Universitas Negeri Padang

Email: yosifimala@gmail.com

\section{Pendahuluan}

Pendidikan merupakan aspek terpenting dalam kehidupan. Namun saat ini proses Pendidikan mendapatkan rintangan yang berat karena dengan adanya pandemic COVID - 19 ini sistem pembelajaran yang awalnya tatap muka beralih menjadi tatap maya/ virtual. Dalam pembelajaran seperti saat sekarang ini motivasi peserta didik harus lebih ditingkatkan lagi. Orang tua dan guru berperan dalam memotivasi siswa belajar. Motivasi adalah dorongan untuk melakukan suatu kegiatan. Pada artikel ini akan dipaparkan mengenai peran orang tua dan guru dalam meningkatkan motivasi peserta didik sekolah dasar pada masa pandemic. 


\section{Metode}

Metode yang digunakan pada penelitian ini adalah study literatur research atau studi kepustakaan dengan mengkaji jurnal yang memiliki kaitan atau hubungan dengan strategi atau upaya orang tua dan guru dalam meningkatkan motivasi peserta didik di sekolah dasar. Metode studi kepustakaan menurut Sugiyono (2018) adalah suatu metode yang mana mengumpulkan kajian teori dan referensi yang bersumber dari literaturliteratur ilmiah. Jadi dalam metode studi kepustakaan ini peneliti tidak perlu turun ke lapangan untuk mencari informasi, melainkan cukup dengan mengkaji serta menyimpulkan berdasarkan sumber yang didapat dari berbagai literatur. Penelitian ini bertujuan untuk menjelaskan peran guru dan orang tua dalam meningkatkan motivasi peserta didik sekolah dasar pada masa pandemi.

\section{Pembahasan}

Hasil dari artikel ini diperoleh dengan cara mencari, meninjau dan menelaah jurnal- jurnal serta referensi yang terkait dengan strategi atau upaya orang tua dan guru dalam meningkatkan motivasi belajar peserta didik sekolah dasar pada masa pandemic. Artikel ini terbatas pada motivasi dari guru dan orang tua saja. Diharapkan penelitian selanjutnya dapat mengkaji lebih dalam lagi dan diperluas tak hanya motivasi saja.

Dalam dunia pendidikan, terutama bagi siswa sekolah dasar, motivasi memegang peranan penting terhadap prestasi dan capaian belajar peserta didik. Motivasi memiliki peran yang sangat signifikan dalam menentukan hasil dari proses pembelajaran (Wahyuni, 2020). Motivasi belajar menurut (Uno, 2021) adalah dorongan internal dan eksternal pada siswa-siswa yang sedang belajar untuk mengadakan perubahan tingkah laku, pada umumnya dengan beberapa indikator atau unsur yang mendukung. Motivasi adalah serangkaian usaha untuk menyediakan kondisi-kondisi tertentu, sehingga seseorang mau dan ingin melakukan sesuatu dan bila tidak suka maka akan berusaha untuk meniadakan atau mengelakkan perasaan tidak suka itu (Emda, 2018).

Setiap kegiatan yang dilakukan pasti didasari oleh adanya motivasi, begitu juga dengan belajar perlu motivasi. Adapun fungsi motivasi yang dikemukakan oleh (Sardiman, 2020) yaitu (1) motivasi menjadi suatu penggerak dari setiap kegiatan yang akan dilakukan, (2) motivasi dapat menentukan arah kegiatan yang akan dilakukan sehingga dapat mencapai tujuan, (3) motivasi dapat menyeleksi perbuatan yaitu, menentukan perbuatan yang harus dikerjakan dan menyisihkan perbuatan yang tidak bermanfaat bagi tujuan. Sedangkan menurut Hamalik (2011) fungsi motivasi diantaranya, (1) motivasi mendorong timbulnya kelakuan atau suatu perbuatan seperti belajar, (2) motivasi mengarahkan perbuatan mencapai tujuan yang diinginkan, (3) motivasi berfungsi sebagai penggerak yang akan menentukan cepat atau lambatnya kita mencapai tujuan.

Guru dan orang tua hendaknya bisa memotivasi anaknya. Motivasi belajar merupakan salah satu faktor pendukung keberhasilan pencapaian tujuan belajar tiap individu. Keseimbangan motivasi belajar yang baik akan membuat individu mampu mengerti tujuan dari pembelajaran yang dialami dan berperan aktif dalam meraih prestasi (Syachtiyani \& Trisnawati, 2021). Motivasi yang tepat akan memancing peserta didik untuk lebih giat belajar. Jika peserta didik sudah merasa memiliki motivasi maka ia akan mampu untuk meminimalisir rasa bosan atau tak nyaman dalam belajar. Jadi motivasi adalah jantungnya proses belajar, maka motivasi yang diberikan oleh orang tua dan guru berdampak besar terhadap motivasi belajar anak. pola asuh orang tua terhadap motivasi belajar siswa serta terdapat hubungan positif antara pembelajaran daring terhadap motivasi siswa (Kurnianto \& Rahmawati, 2020).

Peningkatan motivasi belajar adalah dengan memanfaatkan Teknologi Informasi dan Komunikasi (TIK) Disekolah. TIK telah menjadi entitas umum di semua aspek kehidupan, selama dua pluh tahun terakhir penggunaan TIK telah secara mendasar mengubah praktik dan prosedur dari hampir semua bentuk usaha dalam bisnis dan pemerintah.

Guru memegang peranan penting untuk memberikan motivasi agar dapat membuat siswa tertarik dalam belajar. Dalam membuat siswa agar termotivasi dapat dilakukan dari cara berkomunikasi. Salah satu cara berkomunikasi guru yang dapat digunakan adalah dengan komunikasi persuasive (Suryaningsih, 2020). Komunikasi persuasif adalah penyampaian pesan oleh guru berupa ajakan dan panduan untuk melakukan kegiatan pembelajaran. Dengan komunikasi persuasif tepat sasaran, siswa bisa merasa percaya diri untuk menjalankan pembelajaran daring sehingga terhindar dari rasa jenuh dan memperoleh motivasi yang kuat untuk belajar (Christy \& Oktavianti, 2021). Selain itu guru juga dapat melakukan pengelolaan kelas meliputi mendesain, mengorganisasikan, monitoring dan mengevaluasi pengelolaan pembelajaran dalam rangka memotivasi peserta didik (Sumar, 2020). 
Dalam upaya peningkatan motivasi belajar peserta didik, maka guru dapat melakukan pendekatan personal terhadap peserta didik yang tujuannya untuk memberikan bimbingan dan bantuan secara individu kepada peserta didik. Pendekatan personal ini mendukung adanya perbedaan antar siswa sehingga dengan adanya pendekatan personal memungkinkan potensi- potensi unik siswa dapat berkembang optimal (Zain, 2017).

Dalam belajar, tidak hanya guru yang berperan dalam meningkatkan motivasi belajar peserta didik, namun peranan orang tua juga penting. Jika peserta didik memiliki motivasi yang rendah maka akan berdampak terhadap prestasi belajarnya. Keberhasilan dalam proses pembelajaran tak luput dari adanya motivasi yang menjadi faktor pendorong dan penggerak peserta didik agar dapat melaksanakan kegiatan pembelajaran. Motivasi belajar dapat berasal dari dalam dan luar diri peserta didik. Kedua motivasi tersebut memberikan pengaruh besar terhadap keberhasilan peserta didik.

Menurut (Rumbewas et al., 2018) orang tua dapat memotivasi anaknya untuk belajar dengan beberapa cara yaitu mengatur waktu belajar anak, memantau dan memeriksa perkembangan akademik anak, memantau perkembangan kepribadian anak, memantau efektivitas dan aktivitas belajar anak di sekolah.

Orang tua juga berperan sebagai pendamping dan sebagai motivator anak, sehingga orang tua mempunyai keterlibatan langsung dalam kegiatan pembelajaran dan pendidikan anak. (Lilawati, 2020). Orang tua dan Guru hendaklah membangun kolaborasi demi memaksimalkan kegiatan belajar anak (Iftitah \& Anawaty, 2020). Dalam masa pandemic ini, saat anak melakukan pembelajaran dari rumah maka orang tua sangat berperan penting memotivasi anak demi keberhasilan anak dalam belajar (Hayati, 2020).

Peranan orangtua secara umum dapat dikatakan mempunyai hubungan positif terhadap motivasi belajar dan prestasi belajar anak disebabkan anak membutukan bimbingan dan pengawasan orangtua dalam banak belajar sangat memerlukan bimbingan belajar. Keluarga bagian ilmu social dikenal oleh anak. keutuhan anak contohnya: anak dalam belajar membutuhkan bimbingan atau pengawasan orangtua, sehingga anak biasa termotivasi untuk belajar (Rahmah \& Hamid, 2020).

Peran orang tua saat pembelajaran dilaksanakan dari rumah adalah: 1 . Orang tua sebagai fasilitator yaitu orang tua hendaklah melengkapi sarana dan prasarana anak untuk belajar, 2. Orang tua berperan membimbing anak belajar dari rumah, 3. Orang tua juga menjadi motivator bagi anak yang hendaknya memberikan semangat dan dukungan terhadap anak sehingga anak bersemangat untuk belajar (Cahyati \& Kusumah, 2020).

Orang tua merupakan sumber pendidikan pertama dalam keluarga, dimana orang tua harus menanamkan dasar- dasar pendidikan terhadap anaknya. Orang tua berperan untuk melengkapi program atau aturan terstruktur dalam belajar dirumah dan sarana pendidikan anak dirumah. Dalam rangka memotivasi anak belajar dirumah orang tua harus memperhatikan anak belajar, mengatur waktu dan melengkapi kebutuhan alat belajar anak, memantau kemajuan belajar, dan meninjau kesulitan yang dialami anak dalam belajar (Hero \& Sni, 2018).

Motivasi sangat dibutuhkan dalam proses belajar. Dalam masa pandemic ini guru dituntut untuk lebih memotivasi siswa saat belajar dirumah. Adapun upaya yang dapat dilakukan adalah guru hendaklah menyiapkan media belajar yang inovatif dan mudah diakses serta mudah digunakan, menjadikan siswa aktif belajar, meningkatkan antusias dan semangat dalam mengajar, memberikan penghargaan sehingga siswa selalu ingin menjadi yang terbaik dalam proses dan pencapaian belajar (Suhaemi et al., 2020).

Motivasi dan dukungan yang diberikan oleh guru dan orang tua sangat penting bagi peserta didik terhadap proses pembelajaran, jadi peran guru dan orang tua adalah menyediakan fasilitas, memberikan dukungan untuk mengerjakan tugas sehingga akan sangat membantu peserta didik (Rahmawati et al., 2020). Orang tua berperan sebagai pendidik anak, pelengkap kebutuhan anak, pemberian pemahaman spiritual pada anak, pemantau kegiatan anak, memotivasi dan penyedia fasilitas yang dibutuhkan anak (Yulianingsih et al., 2020).

Orang tua memiliki peran yang banyak dalam membimbing anak, apalagi saat masa pandemic ini. Salah satu peran orang tua adalah membuat anak untuk selalu rajin belajar walaupun secara daring. Beberapa cara yang dapat dilakukan orang tua yaitu mengawasi dan memperhatikan tugas yang dikerjakan oleh anak, memotivasi anak dalam pembelajaran serta menyusun jadwal anak untuk belajar. Dengan begini diharapkan anak bersemangat dan tertarik untuk belajar di rumah (Aziza \& Yunus, 2020). Selain itu dalam memotivasi anak orangtua juga dapat memberikan reward saat anak belajar teratur dan memperoleh capaian hasil belajar yang baik (Aljena et al., 2020). 
Dalam rangka memberikan motivasi kepada peserta didik, guru dapat melakukan pendekatan melalui motivasi materi pelajaran maupun pendekatan lewat cerita inspiratif. Pendekatan motivasi materi pembelajaran diberikan dengan cara mengaitkan materi pembelajaran dengan kehidupan nyata yang dekat dengan anak agar anak terangsang, kagum dan tertarik terhadap pelajaran yang akan ia pelajari, sedangkan pendekatan motivasi lewat cerita inspiratif dapat diberikan dengan menceritakan ketekunan tokoh ilmuan dalam belajar atau dapat juga dengan menceritakan pengalaman pendidik sendiri (Lutfiyah \& Roviati, 2020).

Peran orang tua dalam membantu pencapaian prestasi belajar anak meliputi: 1) Memberikan kesempatan kepada anak untuk menemukan minat dan bakat yang ada pada dirinya; 2) Memberikan informasi penting yang sesuai dengan minat dan bakat anak; 4) Memberikan fasilitas untuk membantu kesulitan anak dalam belajar.

Dalam pembelajaran, orang tua harus mampu menjadi motivator bagi anaknya. Hal itu dilakukan untuk membimbing anak belajar dengan kasih sayang yang penuh, serta dengan mewujudkan suasana nyaman untuk belajar di rumah. Suasana belajar yang nyaman dapat terwujud dengan mengurangi kebiasaan yang tidak bermanfaat (Umar, 2015). Selain itu orang tua juga dapat memberikan motivasi berbasis spiritual karena kedekatan anak dan ibadah anak juga bisa meningkatkan motivasi belajarnya (Rianita et al., 2020). Dalam masa pandemi ini, untuk meningkatkan motivasi belajar anak, guru dapat membuat pembelajaran daring menjadi semenarik mungkin misalnya dalam pemberian tugas tidak sebatas pemberian tugas saja melainkan bisa dikreasikan dengan membuatnya pada aplikasi/ platform kuis yang online yang bisa ditambahkan gambar- gambar dan suara yang menarik (Syafari \& Montessori, 2021).

\section{Simpulan}

Peranan orang tua dan guru dalam rangka memotivasi anak belajar di rumah dapat membentuk komunikasi persuasif, pendekatan personal, mengawasi cara belajar anak dan mengatur waktu belajar anak, memantau perkembangan belajar anak, melakukan pendampingan, memfasilitasi sarana prasarana belajar, membangun kolaborasi antara orang tua dan guru, memaksimalkan peran sebagai fasilitator dan motivator, melengkapi program atau aturan terstruktur dalam belajar dirumah, menyiapkan media belajar yang inovatif dan mudah diakses serta mudah digunakan, memberikan dukungan untuk mengerjakan tugas, memberikan kesempatan anak untuk menemukan minat dan bakat yang ada pada dirinya, serta memberikan informasi penting yang sesuai dengan minat dan bakat anak, kemudian melengkapi kebutuhan anak dalam belajar dan menangani kesulitan belajarnya.

\section{Referensi}

Aljena, S. C., Andari, K. D. W., \& Kartini, K. (2020). Pengaruh reward terhadap motivasi belajar siswa. Jurnal Pendidikan Dasar Borneo, 1(2), 127-137.

Aziza, F. N., \& Yunus, M. (2020). Peran Orang Tua Dalam Membimbing Anak Pada Masa Study From Home Selama Pandemi Covid 19. UrbanGreen Conference Proceeding Library, 1, 112-114.

Cahyati, N., \& Kusumah, R. (2020). Peran orang tua dalam menerapkan pembelajaran di rumah saat pandemi Covid 19. Jurnal Golden Age, 4(01), 152-159.

Christy, N. J., \& Oktavianti, R. (2021). Pengaruh Komunikasi Persuasif Guru terhadap Motivasi Belajar Siswa Saat Pandemi COVID-19 (Vol. 5, Issue 1, pp. 187-193). https://doi.org/10.24912/KN.V5I1.10231

Emda, A. (2018). Kedudukan motivasi belajar siswa dalam pembelajaran. Lantanida Journal, 5(2), 172-182.

Hayati, A. S. (2020). Peran Orang Tua dalam Meningkatkan Motivasi Belajar Anak Dengan Sistem Daring pada Masa Pandemi di Desa Depokrejo, Kebumen. TASYRI': JURNAL TARBIYAH-SYARI'AH ISLAMIYAH, 27(2), 23-32.

Hero, H., \& Sni, M. E. (2018). Peran Orang Tua dalam Meningkatkan Motivasi Belajar Siswa Kelas V di Sekolah Dasar Inpres Iligetang. JRPD (Jurnal Riset Pendidikan Dasar), 1(2), 129-139.

Iftitah, S. L., \& Anawaty, M. F. (2020). Peran Orang Tua Dalam Mendampingi Anak Di Rumah Selama Pandemi Covid-19. JCE (Journal of Childhood Education), 4(2), 71-81.

Kurnianto, B., \& Rahmawati, R. D. (2020). Hubungan Pola Asuh Orang Tua terhadap Motivasi Belajar Siswa Pada Pembelajaran Daring Masa Pandemi. Seminar Pendidikan Nasional (SENDIKA), 2(1).

Lilawati, A. (2020). Peran Orang Tua dalam Mendukung Kegiatan Pembelajaran di Rumah pada Masa Pandemi. Jurnal Obsesi: Jurnal Pendidikan Anak Usia Dini, 5(1), 549-558.

Lutfiyah, L., \& Roviati, E. (2020). Pendampingan Belajar Di Rumah Selama Masa Pandemi Covid-19. Dimasejati: Jurnal Pengabdian Kepada Masyarakat, 2(2), 181-190.

Rahmah, R., \& Hamid, S. (2020). Pola Asuh Orangtua Terhadap Dorongan Aktivitas Belajar dan Hasil Belajar Siswa Sekolah Dasar Di Kabupaten Maros. Bosowa Journal of Education, 1(1), 1-4. 
Rahmawati, N. R., Rosida, F. E., \& Kholidin, F. I. (2020). Analisis Pembelajaran Daring saat Pandemi di Madrasah Ibtidaiyah. SITTAH: Journal of Primary Education, 1(2), 139-148.

Rianita, N. M., Trisnawati, N. L. D. E., \& Nopiyani, P. E. (2020). Peningkatan Motivasi Belajar Berbasis Spiritual Terhadap Hasil Belajar Mahasiswa. Mimbar Ilmu, 25(3).

Rumbewas, S. S., Laka, B. M., \& Meokbun, N. (2018). Peran Orang Tua Dalam Miningkatkan Motivasi Belajar Peserta Didik di Sd Negeri Saribi. EduMatSains: Jurnal Pendidikan, Matematika Dan Sains, 2(2), 201-212.

Sardiman, A. M. (2020). Interaksi \& motivasi belajar mengajar.

Suhaemi, A. N., Laurenza, D., Pandu, F. B., \& Abhista, D. P. (2020). Peran guru dalam meningkatkan motivasi belajar daring di era pandemi covid-19. Seminar Nasional Ilmu Pendidikan Dan Multi Disiplin 3 (SNIPMD 3). ISBN: 978-623-6566-35-0, 3.

Sumar, W. T. (2020). Pengelolaan Kelas dalam Meningkatkan Motivasi Belajar siswa. Jambura Journal of Educational Management, 49-59.

Suryaningsih, A. (2020). Peningkatan motivasi belajar siswa secara online pada pelajaran animasi $2 \mathrm{~d}$ melalui strategi komunikasi persuasif. Ideguru: Jurnal Karya Ilmiah Guru, 5(1), 9-15.

Syachtiyani, W. R., \& Trisnawati, N. (2021). Analisis Motivasi Belajar Dan Hasil Belajar Siswa Di Masa Pandemi Covid-19. Prima Magistra: Jurnal Ilmiah Kependidikan, 2(1), 90-101.

Syafari, Y., \& Montessori, M. (2021). Analisis Pembelajaran Daring Terhadap Motivasi Belajar Dan Prestasi Belajar Siswa Dimasa Pandemi Covid-19 (Vol. 5, Issue 3, pp. 1294-1300). https://doi.org/10.31004/BASICEDU.V5I3.872

Umar, M. (2015). Peranan orang tua dalam peningkatan prestasi belajar anak. JURNAL EDUKASI: Jurnal Bimbingan Konseling, 1(1), 20-28.

Uno, H. B. (2021). Teori motivasi dan pengukurannya: Analisis di bidang pendidikan. Bumi Aksara.

Yulianingsih, W., Suhanadji, S., Nugroho, R., \& Mustakim, M. (2020). Keterlibatan Orangtua dalam Pendampingan Belajar Anak selama Masa Pandemi Covid-19. Jurnal Obsesi: Jurnal Pendidikan Anak Usia Dini, 5(2), 1138-1150.

Zain, N. L. (2017). Strategi Komunikasi Persuasif Dalam Meningkatkan Motivasi Belajar Siswa. Jurnal Nomosleca, 3(2). 